\title{
CORPORATE REAL ESTATE DISPOSAL IMPACT ON PERFORMANCE RATIOS
}

\author{
Antti LOUKO \\ Helsinki University of Technology, Real Estate Studies, P.O. Box 1200, FIN-02015 HUT, Finland tel: \\ +3589451 3877; fax. +3589465 077; e-mail: ajlouko@cc.hut.fi
}

Received 15 April 2004; accepted 13 August 2004

\begin{abstract}
The purpose of this study was to investigate the effects of corporate real estate disposals on corporate performance ratios in Europe between the years 1998-2002. In addition, it was studied whether the retail and telecom corporations that conducted large real estate disposals were in significantly worse condition before the transactions than other corporations in the same business sector. The study indicated that those retail corporations that had divested corporate real estate were less profitable compared to other corporations in the same business sector before the transactions. Similarly, some evidence was found that the telecom corporations that were disposing of real estate had worse capital structure and short-term solvency before the transactions than other European telecom corporations. It seems, however, that the overall economical environment and other corporate operations have often influenced the development of the performance ratios more than the property disposals, at least in the most volatile business sectors.
\end{abstract}

KEYWORDS: Corporate real estate disposal; Sale and leaseback; Profitability; Capital structure; Solvency

\section{INTRODUCTION AND MOTIVATION}

Disposals of operational corporate real estate have become increasingly common during the past decade in the western and northern Europe. Similar development of corporate real estate sale and leasebacks (SLB) began much earlier in the US, where corporations currently own clearly less of their operational real estate than corporations in Europe. For instance, Zeckhauser and Silverman (1983) indicated in a paper published in the Harvard Business Review, that corporate real estate comprised anywhere from $25 \%$ to $40 \%$ of total assets of the US corporations. In 2002 NappiChoulet estimated that the same figure was approx. $15 \%$ in the US and approx. 35-40\%' in Europe. Moreover, the significant difference in the property assets to total assets ratio between European and US corporations indicate that there is little reason to expect the trend of European corporate real estate disposals not to continue (Laposa and Charlton 2001).

There have been signs indicating that a significant part of corporations that have disposed of operational corporate real estate have been in financial distress or have had particularly large real estate holdings as opposed to other similar corporations or corporation's own market capitalization. This has many times lead to worse performance ratios, because real estate does not usually yield as much as the core business and ties a lot of capital resources. Therefore, one of the immediate reasons for the divestments of operational corporate real estate has been the need to lighten corporate balance sheet and redirect the capital into core business areas. This could enhance key performance ratios, such as profitability, capital structure and liquidity ratios, depending on how the obtained capital is used.

There is a great deal of literature regard- 
ing real estate sale and leasebacks, as well as, the decision of real estate leasing versus buying. However, only a small amount of empirical research has been conducted to discover the true effects of sale and leaseback and disposal decisions on the corporate performance. Previous empirical research in this field has concentrated on stock market reactions of the real estate sale and leasebacks and spin-offs. In addition to these, some studies have investigated the stock market reactions of real estate leasing, acquisition and divestment decisions. The research community has, hence, neglected empirical research regarding the impact of real estate sale and leasebacks and disposals on the corporate balance sheet and performance ratios. This is so despite researchers studying sale and leasebacks generally acknowledge that the improvement of balance sheet and performance ratios are one of the largest reasons for disposals and leasebacks of corporate real estate.

\subsection{Performance ratios and asset SLBs}

Leasing has generally been a way to obtain offbalance sheet finance. Traditionally, in many countries, lease contracts have not been shown either on the asset or on the liabilities side of the balance sheet. This has ultimately led to a situation, where it has been possible for corporations to raise funds for fixed asset investments without taking additional debt through leasing arrangements. Therefore, many corporations have been tempted to change their real asset holdings into cash through sale and leasebacks and reduce debt, which usually enhances profitability ratios, such as return on total assets and return on invested capital. On the other hand, profitability ratios can also be enhanced by redirecting the released capital into investments in the corporate core business areas, considered that these investments yield more than the corporate real estate assets. However, in order to be able to create economic profit (EVA) and shareholder value, the corporation should find investment oppor- tunities, which yield more than the corporate weighted average cost of capital (WACC) as Stern and Stewart showed in 1983. Therefore, if a corporation cannot invest with an internal rate of return (IRR) that exceeds its WACC, it should not carry out the investment. In theory, it could be justifiable in these situations to distribute the excess capital back to the shareholders as dividends, or through share buy-back programs to maximise the shareholder value, considered that reducing of debt is not an option.

In addition to capital-use efficiency, the corporation should be concerned about the efficiency of its real estate asset management. It should be noted that it is acceptable to carry out real estate disposals only if the corporation benefits from more efficient space-use and the corporate real estate is more efficiently managed by a professional real estate investor. Otherwise, the advantages from the more efficient capital use must outnumber the losses in real estate management efficiency. The possibility to add value with leasing originates from the fact that some real estate market operators can manage real estate and related risks more efficiently than others (e.g., Benjamin, de la Torre and Musumeci 1998).

Thus, it could be summarised that there are at least three areas where corporations might be able to obtain efficiency gains through real estate outsourcing. These are 1) corporate capital-use, 2) corporate space-use and 3) corporate real estate asset management.

\subsection{Asset SLBs and shareholder value maximisation}

It is already known that smaller corporations seldom own their facilities in their growth-phase. It is clear that sometimes it might be wise for corporations to finance growth with asset sale and leasebacks, if there are profitable investment opportunities available. However, there are also many examples of corporations (the latest in the IT and telecommunications sector), which have spent the capital 
released from their corporate real estate holdings in very poor investments. In these cases, corporate real estate could have been a good diversifier in a risky corporate asset portfolio. This assumption is supported by Brounen and Eichholtz (2003), who indicate that real estate ownership and systematic risk of a company are negatively correlated. Some claims have also been made that a large part of corporations carrying out asset sale and leasebacks are in financial distress. In many cases, when most other resources have been used for bad investments, real estate assets have come to rescue. Hence, corporate real estate can work as an innovative source of corporate finance and has a proven role as a risk diversifier.

There is evidence that corporations performing asset sale and leasebacks (e.g., Slowin, Sushka and Polonchek (1990) and Alvayay, Rutherford and Smith (1995)) or corporate real estate spin-offs obtain abnormal gains to their stock prices (e.g., Hite, Owers and Rogers (1984) and Ball, Rutherford and Shaw (1993)). A widely held explanation for this is that real estate is a specialised asset that may be undervalued either by managers or the market, or by both (Ball, Rutherford and Shaw 1993). Undervaluation is sometimes explained by inefficient corporate real estate management and/or by the inability of the financial sector to recognise the true risk-return profile of the real estate. Rodriquez and Sirmans (1996) suggest that in corporate real estate sell-offs and spin-offs the value increase is consistent with the hypothesis that corporate values increase when information regarding real estate asset values is provided to the market. On the other hand, according to John (1993), spin-offs increase shareholder wealth by reducing agency costs and increasing the value of tax-shields. Also Slovin, Sushka and Polonchek (1990) suggest that positive market perception results from an overall reduction in the present value of expected taxes. However, based on the hypothesis that managers seek to maximise corporate value, it could also be assumed that corporations carry out sale and leaseback transactions only when it is clear that the transaction could enhance the shareholder wealth. Thus, it cannot be generalised from the previous research findings that corporations can increase their value only by disposing of operational corporate real estate. It can only be hypothesised that in some cases this can be true and that the previous research findings are consistent with the assumption that managers really try to seek ways to maximise shareholder value.

Researchers have also shown that in some asset intensive business sectors corporations may have particularly large real estate holdings in comparison with corporation's market capitalisation. For instance, Wainwright (2000) showed that in many UK based retail corporations the value of corporate real estate assets exceeded the corporate market capitalisation. This can lead to hostile takeover attempts that have also been seen in the past. There are some theories that support this proposition. For instance, Ambrose (1990) provided evidence that the larger the corporate real estate holdings, the greater the likelihood of a company becoming a takeover target. There are also many other empirical studies that indicate that economic benefits are associated with companies that have less real estate on balance sheet (e.g., Kuruvilla 1994, Deng and Gyorko 1999 and Pottinger, Dixon and Marston 2001). Further, Brounen and Eichholtz (2003) indicate that overall real estate ownership has been decreasing over time, which may be due to the raising popularity of lease alternatives. It must be remembered, though, that only a short time ago there were not many options for ownership. Brounen and Eichholtz (2003) also indicate that real estate ownership appears to be driven by industrial differences rather than national variations. Nevertheless, they suggest that the stock market returns are lowest among the companies with highest real estate ownership levels in each industry. This notion strongly supports the assumptions that real estate's risk-return profile is not fully recognised by stock markets, which might be 
due to the stock markets' assumption that the best possible risk-return relationship takes place in corporations that focus solely on their core functions leaving other operations to the best possible service providers.

\section{RESEARCH PROBLEM, DATA AND METHODOLOGY}

\subsection{Research problem}

The study investigates if large operational corporate real estate disposals carried out between the years 1998-2002 in Europe had a positive impact on the seller corporations' performance ratios. In addition, the study focuses on finding out whether the performance ratios of retail and telecom corporations, which carried out major operational real estate disposals between the years 1999-2002 were significantly worse before the transactions than the performance ratios of other corporations at the same business sector. This research paper will answer the following questions. What kind of impact did the large operational real estate disposals have on the corporate performance ratios in general? Did the corporations in the retail and telecom sectors perform significantly worse before the operational real estate disposals than the industry benchmark?

\subsection{Research methodology and data}

Firstly, to find out if the sample corporations' performance ratios were enhanced by the real estate disposals a time-series analysis of corporate financial ratios was performed. The corporations' average performance ratios before the transaction were compared with the average performance ratios after the transactions. Secondly, in order to be able to answer the second research question, the telecom and retail corporations' average performance ratios before the disposals were compared to the respective industry benchmarks, which were separately formed for both business sectors. The analysis is based on the theory of crosssectional financial ratio analysis, in which a specific company is usually compared to another company, the industry average, or some "ideal" benchmark (Foster 1978).

The financial ratios were calculated with the following formulas based on publicly available information in corporate annual and interim reports and web sites (Table 1). Two financial years were taken into account before and after the deal.

The research data consists of three samples. The first sample was formed in order to investigate how corporate real estate disposals have affected corporate performance ratios. This sample consisted of performance ratios of European corporations that have been carrying out major real estate disposals during the past few years. Average corporate performance ratios were calculated for a two-year period before and after the real estate disposals. The sample included only transactions, in which corporations disposed mostly operational real estate, at least $1 \%$ of corporation's total assets and the disposals were worth at least 30 million euros. Furthermore, all the sample corporations were major stock exchange listed corporations, and if more than one transaction was carried out by the same corporation during the same financial year these transactions

Table 1. Formulas used in calculating key performance ratios

$\begin{array}{ll}\begin{array}{l}\text { Return on total assets } \\ \text { Equity ratio }\end{array} & \begin{array}{l}\text { = Total operating profit of the year / Average total assets during the year }(*)= \\ \text { Total equity (incl. provisions and minority shares) in the end of the year / } \\ \text { Total assets in the end of the year }\end{array} \\ \begin{array}{l}\text { Current ratio } \\ \text { Dividend per share }\end{array} & \begin{array}{l}\text { Total current assets in the end of the year / Total current liabilities in the end of the year }(* *) \\ \text { Turnover growth }\end{array} \\ =\text { (Year-end turnover - Beginning of the year turnover) / Beginning of the year turnover }\end{array}$

* Average total assets $=($ Year-end total assets + beginning of the year total assets $) / 2$

** Current assets are assets that can be changed into cash in short-term and current liabilities are debt that is to be paid back in one years time 
were regarded as one disposal. This sample included 22 disposals performed by 18 different companies between the years 1998-2002 (see Table 2). Retail corporations carried out over $30 \%$ of the total value of the sample transactions and telecom corporations almost $64 \%$. Thus, the retail and telecom sectors together were responsible for almost $94 \%$ of the total value of the sample transactions, which is why these two sectors were chosen to be investigated more accurately. Due to the unavailability of financial data of the sample corporations, the study was restricted to transactions that were carried out between the years 1998-2002. The second sample was formed in order to compare whether the retail corporations that disposed large operational corporate real estate portfolios between the years 1999-2002 were

Table 2. The three samples of disposals used in the study

\begin{tabular}{|c|c|c|c|c|}
\hline Sample I & Corporation & Year & Deal value, $m \boldsymbol{\epsilon}$ & Deal value / Assets \\
\hline & Kesko & 1998 & 200,0 & $14,1 \%$ \\
\hline & Kesko & 1999 & 94,1 & $9,6 \%$ \\
\hline & MFI & 1999 & 154,4 & $16,2 \%$ \\
\hline & Metro & 1999 & 2.700 .0 & $25.9 \%$ \\
\hline & WH Smith & 1999 & 57,2 & $5,4 \%$ \\
\hline & Kesko & 2000 & 67,3 & $7,8 \%$ \\
\hline & Marks \& Spencer & 2001 & 580,0 & $5,5 \%$ \\
\hline & Somerfield & 2001 & 39,6 & $1,9 \%$ \\
\hline & Sainsbury & 2000 & 809,3 & $5,3 \%$ \\
\hline & Carrefour & 2001 & $1.500,0$ & $4,7 \%$ \\
\hline & Carrefour & 2002 & 104,0 & $0.3 \%$ \\
\hline & Somerfield & 2002 & 30,0 & $3,9 \%$ \\
\hline & Retail, total & & $6.335,9$ & \\
\hline & Telecom Italia & 2000 & 2.900 .0 & $5,2 \%$ \\
\hline & British Telecom & 2001 & $3.800,0$ & $6,4 \%$ \\
\hline & France Telecom & 2001 & $3.300,0$ & $5.6 \%$ \\
\hline & Sireo / DT & 2001 & $1.100,0$ & $1,3 \%$ \\
\hline & SwissCom & 2001 & $1.635,7$ & $14,0 \%$ \\
\hline & Telecom Italia & 2002 & $1.360,0$ & $7,7 \%$ \\
\hline & Telecom, total & & $14.095,7$ & \\
\hline & Thalès & 2001 & 467,0 & $1,3 \%$ \\
\hline & Ericsson & 2000 & 403,6 & $1,5 \%$ \\
\hline & Thomson Multimedia & 2000 & 91,0 & $1.5 \%$ \\
\hline & SAS & 2001 & 334,4 & $4,8 \%$ \\
\hline & The Hilton Group & 2001 & 448,0 & $5,9 \%$ \\
\hline & \multicolumn{2}{|l|}{ Other, total } & \multicolumn{2}{|l|}{$1.744,0$} \\
\hline & \multicolumn{2}{|l|}{ Total } & \multicolumn{2}{|l|}{$22.175,6$} \\
\hline
\end{tabular}




\begin{tabular}{lllll}
\hline Sample 2 & Corporation & Year & Deal value, me & Deal value / Assets \\
\hline & Kesko & 1999 & 94,1 & $9,6 \%$ \\
& MFI & 1999 & 154,4 & $16,2 \%$ \\
& Metro & 1999 & $2.700,0$ & $25,9 \%$ \\
Kesko & 2000 & 67,3 & $7,8 \%$ \\
Marks \& Spencer & 2001 & 580,0 & $5,5 \%$ \\
& Somerfield & 2001 & 39,6 & $1,9 \%$ \\
& Sainsbury & 2000 & 809,3 & $5,3 \%$ \\
& Carrefour & 2001 & $1,500,0$ & $4,7 \%$ \\
& Carrefour & 2002 & 104,0 & $0,3 \%$ \\
& Somerfield & 2002 & 30,0 & $3,9 \%$ \\
\hline & & & \\
\hline Sample 3 & Corporation & Year & Deal value, $\mathbf{m \in}$ & Deal value / Assets \\
\hline & Telecom Italia & 2000 & $2.900,0$ & $5,2 \%$ \\
& British Telecom & 2001 & $3.800,0$ & $6,4 \%$ \\
& France Telecom & 2001 & $3.300,0$ & $5,6 \%$ \\
& Sireo / DT & 2001 & $1.100,0$ & $1,3 \%$ \\
& SwissCom & 2001 & $1.635,7$ & $14,0 \%$ \\
& Telecom Italia & 2002 & $1.360,0$ & $7,7 \%$ \\
\hline
\end{tabular}

performing worse before the transactions than the industry average (see Table 2). The same criteria were used in choosing the corporations as in the first sample. In addition, the chosen corporations' strategy was to focus only on retail business. The average corporate performance ratios were calculated from a two-year period before the transactions. Kesko's transaction in 1998 was not included in the sample due to the difficulties in obtaining benchmark data from the year 1996. The third sample was formed the same way as the second sample, but this time for the telecom corporations (see Table 2).

\subsection{Industry benchmarks}

Similar data of performance ratios were collected for the benchmark corporations in the telecom and retail sectors. These two samples of time-series financial data were used as in- dustry benchmarks for telecom and retail sectors that together formed almost $94 \%$ of the operational corporate real estate disposals performed by major stock exchange listed companies in Western Europe between the years 19982002. The same average and median performance ratios were calculated from the same period of time for these corporations in order to be able to compare them to the sample corporations.

The industry benchmark for telecom corporations was formed from the rest of the major western European former governmental telecom corporations. Thus, the industry benchmark for telecom corporations included the following nine corporations: Aust-riaTelecom, Elisa from Finland, Dutch KPN, Portugal Telecom, Finnish Sonera, Spanish Telefonica, TeleDanmark, Norwegian Telenor and Swedish Telia.

The corporations forming the retail indus- 
try benchmark were generating most of their revenues in mixed retail businesses usually both outof-town and high street locations as most corporations in the retail sample. Similarly, the emphasis of the retail industry benchmark was on the UK market, which was also the case with the retail company sample. In addition, the corporations chosen for the retail industry benchmark were all stock-exchange listed and significant retailers in their own markets. Moreover, the availability of satisfactory time-series of financial data was an important reason for choosing the particular corporations. Retail industry benchmark consisted of Swedish Axfood, Dutch Ahold, Wal-Mart from the US, French Pinault-Printemps-Redout, Finnish Stockmann and UK companies; Body Shop International, Boots, Debenhams, Great Universal Stores, Iceland, John Lewis, Safeway, Selfridges and Tesco. US-based Wal-Mart was included in the sample, because of its large market share in the groceries worldwide. For the year 1997 (and partly for 1998), the amount of corporations in the retail industry benchmark varies from 11 to 14 depending on the performance ratio, because of difficulties in obtaining appropriate financial data for these years concerning four corporations.

\section{THE SLB EFFECT ON CORPORATE PERFORMANCE RATIOS}

The following table (Table 3) summarises the sale and leaseback effect on the corporate performance ratios. One-fifth of the sample corporations divested over $10 \%$, and $65 \%$ of them divested over $5 \%$ of their total assets in these transactions. All of the corporations that divested over $10 \%$ of their total assets were able to improve their return of total assets, and $75 \%$ (three out of four) were able to reduce the amount of debt in the corporation and/or to improve short-term solvency.

An analysis of the real estate disposal effect indicates that the overall descending business cycle in Europe between the years 2000-2003 and other corporate operations seemed to be generally more influential factors in the corporations' performance in terms of their performance measures than the real estate disposal programs. However, yet about half of all the corporations that were studied were able to improve their profitability (12 out of 22 corporations), capital structure ( 9 out of 22 ) or short-term solvency (10 out of 22). In addition, 10 out of the total 22 corporations increased their dividend payments after the sale and leasebacks, out of which nine were retailers.

It must be noted that only very few corporations were generally able to improve their performance during this period of low economical growth. For instance, the corporations that were used as industry benchmarks for the retail and telecom sector (see the section 4) show that the median return on assets (ROA) for retail corporations was $10.44 \%$ in 1998 , and $7.69 \%$ in 2002 . Further, in terms of the telecom corporations this fast downslide was even clearer. The median ROA for the telecom sector was $10.65 \%$ in 1998 and $1.88 \%$ in 2002. Thus, it is not surprising that the disposal impact was more evident in the more solid retail corporations than in the telecom sector. The large investments in new technology in the telecom sector and licenses in the Universal Mobile Telecommunications System (UMTS) in the beginning of this millennium have clearly had the most significant effect on telecom corporations' key figures and performance.

\subsection{Different industries}

When investigating the disposal effects on the corporate key figures only in the retail industry, it can be noticed that nine out of the total twelve corporations have been able to improve their average return on total assets after the disposal (Table 4), when at the same time only three out of the ten other corporations succeeded in this. In addition, it is interesting to notice that similarly nine out of the total twelve retail corporations have increased their dividend payments after the real estate sell-offs when at the same time only one cor- 


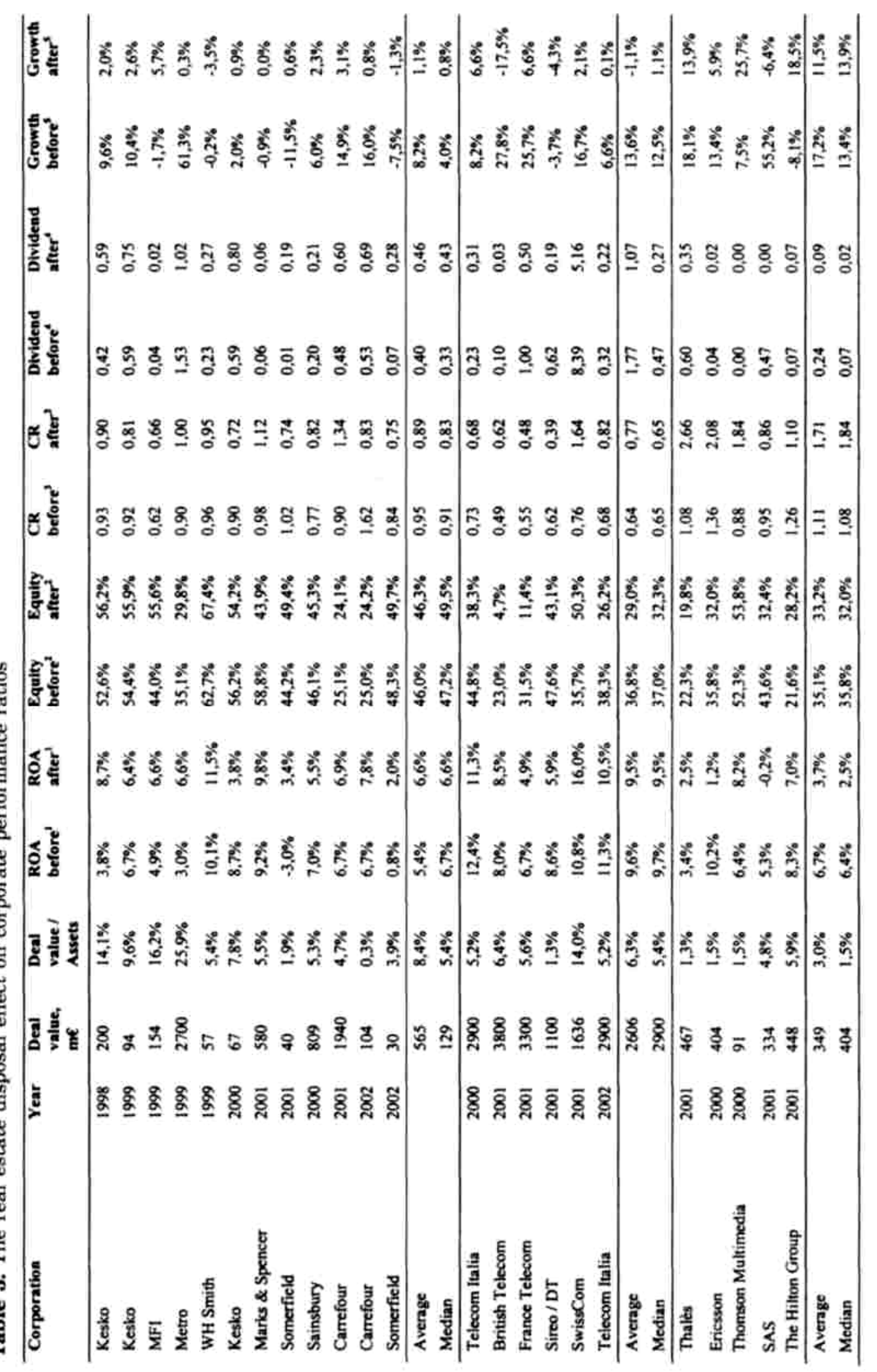


Table 4. The disposal impact on avg. performance ratios

\begin{tabular}{|c|c|c|c|}
\hline & Increased & No change & Decreased \\
\hline ROA & 12 & & 10 \\
\hline Retail & 9 & & 3 \\
\hline Telecom & 2 & & 3 \\
\hline Other & 1 & & 4 \\
\hline Equity ratio & 9 & & 13 \\
\hline Retail & 6 & & 6 \\
\hline Telecom & 1 & & 4 \\
\hline Other & 2 & & 3 \\
\hline Current ratio & 10 & & 12 \\
\hline Retail & 5 & & 7 \\
\hline Telecom & 2 & & 3 \\
\hline Other & 3 & & 2 \\
\hline Turnover growth & 6 & & 16 \\
\hline Retail & 4 & & 8 \\
\hline Telecom & & & 5 \\
\hline Other & 2 & & 3 \\
\hline Dividend per share & 10 & 3 & 9 \\
\hline Retail & 9 & 1 & 2 \\
\hline Telecom & 1 & & 4 \\
\hline Other & & 2 & 3 \\
\hline
\end{tabular}

poration out of all other business sectors managed to do this. Also retail companies' average and median key figures indicate that the disposal effect has been the clearest in the retail sector. For instance, the average return on assets, and both average and median dividend per share increased after the transactions among the retail companies. Furthermore, retail companies' average and median equity ratios were larger after the transactions than before. Therefore, it is clear that the real estate selloffs' impact on the corporate performance is easiest to notice in the more solid business sectors such as retail.

On the other hand, also the sizes of the real estate disposals in comparison with the corporation's total assets have generally been much larger in the retail sector than in the telecom sector or in the 'others' category. When the retail corporations sold on average $8,4 \%$ of their total assets in these real estate disposals, the telecom corporations sold on average $6.3 \%$ and the rest of the corporations only $3,0 \%$ of their totals assets. Because of the gigantic sizes of telecom corporations' balance sheets, the huge corporate real estate disposals had not relatively as large significance as much smaller disposals in other corporate sectors. The huge investments in new technology in the beginning of this century swelled the telecom corporations' balance sheets and hence made it difficult to separate the real estate disposal effect on the corporate performance from other corporate operations. This is even though the disposed amount of assets in euros has 
generally been clearly the largest among the telecom companies.

\section{CORPORATE PERFORMANCE BEFORE THE DISPOSALS}

\subsection{Retail corporations}

The retail corporations that carried out largescale operational real estate disposals have clearly been performing worse than the industry benchmark before the transactions, as the Table 5 shows. Although most of the retail corporations' performance ratios were worse than the industry benchmark before the transactions, the largest difference was in the return on total assets.

Thus, the retail corporations that disposed of operational corporate real estate were less profitable than corporations generally in the same business sector before the transactions. The only exception was Marks \& Spencer, which were performing slightly better than the industry on average before the transactions, but this was only in average terms. Nevertheless, Marks \& Spencer have traditionally been a very profitable corporation, which begun to perform worse than usual during the late-90s. Thus, the disposal was partly intended to enhance the corporate performance.

We cannot draw any overall conclusions of the corporations' capital structure, short-term solvency or turnover growth, although the industry averages and medians have overall been higher than in the sample, and in some cases corporations' capital structure and short-term solvency have been clearly worse than the industry benchmark. For instance, Carrefour and Metro had much worse capital structure than the industry in general, because of a very fast growth period before the transactions. Carrefour's turnover grew approx. $36.3 \%$ in 1998 and $73.4 \%$ in 1999 due to mergers and acquisitions becoming the world's second largest and Europe's largest retailer (merged with Promodès in 1999). Similarly, Metro's turnover growth was $61.3 \%$ in 1997 due to a heavily in- ternational investment program and expansion (acquisitions of Allkauf in Germany and European C\&C operations of SHV Makro NV during 1997).

As a whole, in six out of ten disposal cases the corporation has had more leverage than the industry in general, and in seven out of ten disposals the seller-corporation has had worse current ratio than the industry benchmark before the transactions (see Table 5).

The industry benchmark performance ratios provided by Reuters also support the assumptions (Table 6). However, the Reuters industry average shown below is mostly based on the corporations in the US market and therefore the figures are not fully comparable with the sample corporations. In addition, the time period is very different and the calculation method can also differ. Nevertheless, it clearly seems that most of the corporations that have been selling corporate real estate in the retail sector in Europe have been performing worse than usual, at least in terms of return on total assets.

\subsection{Telecom corporations}

Table 7 below shows the average before transaction performance ratios of the corporations that disposed of operational corporate real estate in the telecom sector during the years 1999-2002. In most cases the corporations that carried out these real estate disposals in the telecom sector were in worse condition in terms of capital structure and short-term solvency than other corporations in the same sector at the same time. Only Deutsche Telecom had clearly better situation in terms of equity ratio than the industry before the disposals. Telecom Italia was also very close to the equity ratio levels of the industry benchmark, but when it comes to short-term solvency all the sample corporations had much lower amount of short-term capital compared to short-term liabilities as opposed to the industry in general.

Nevertheless, in four out of six cases the 

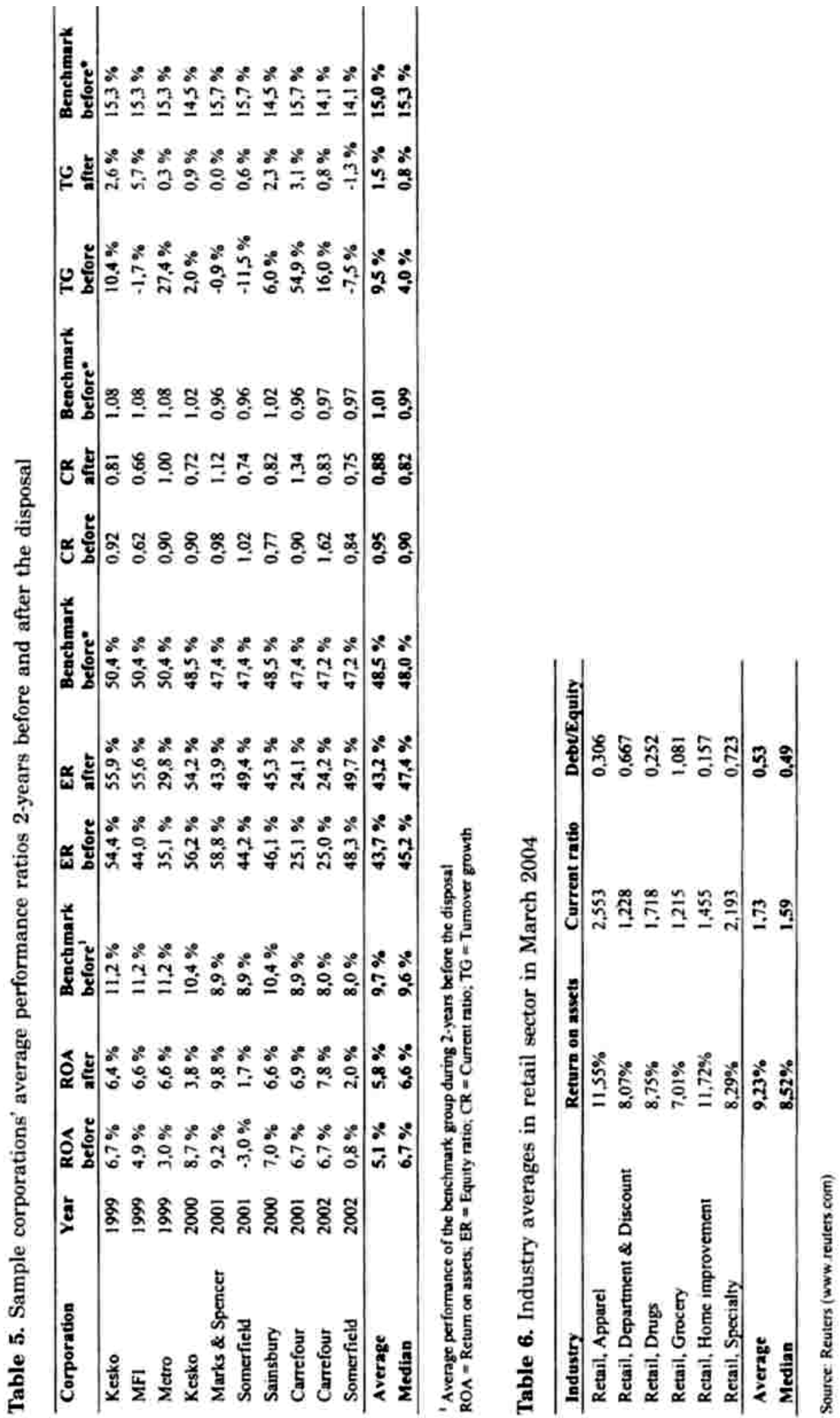


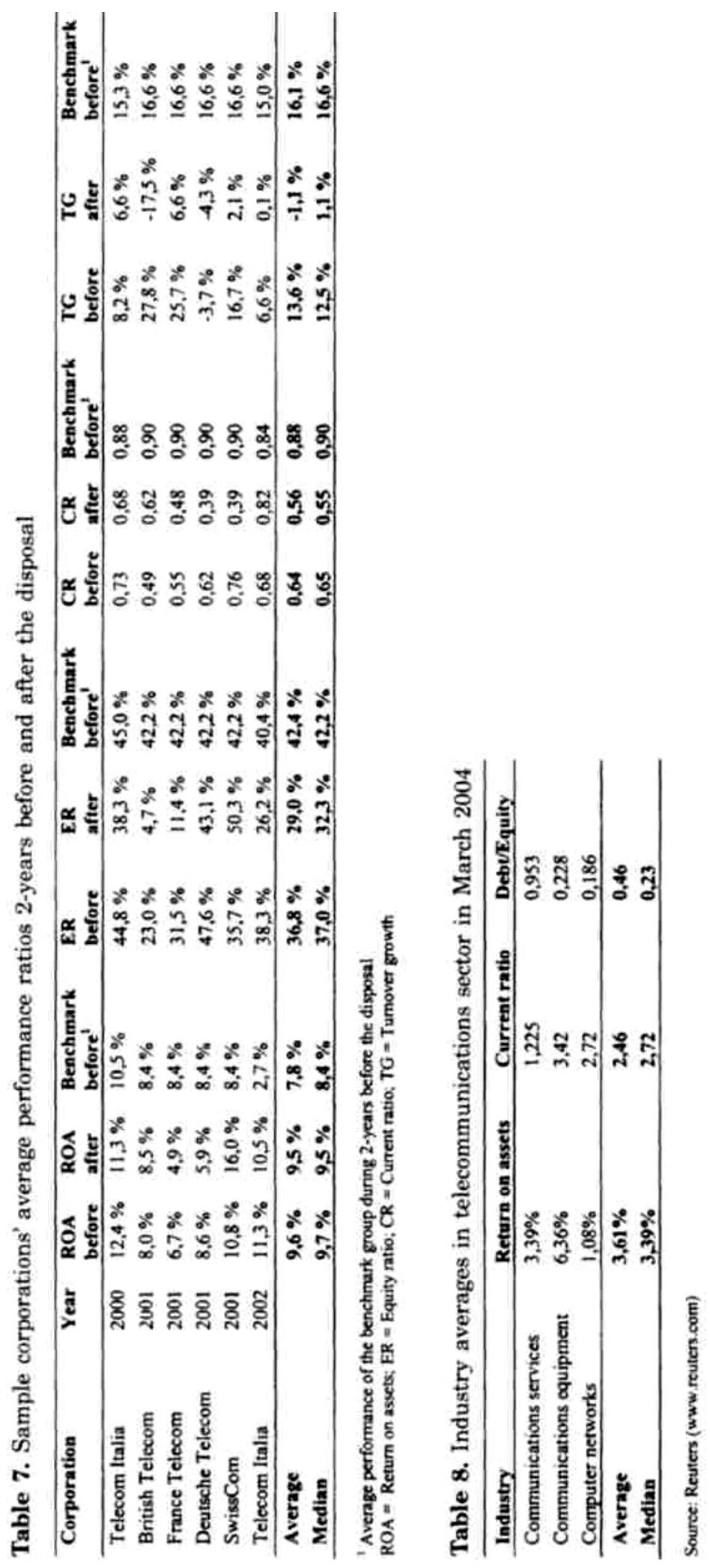


seller corporations' profitability had exceeded the industry average (Table 7). In addition, as Carrefour and Metro in the retail sector also some corporations in the telecom sector (mainly British Telecom and France Telecom) were growing faster than the industry benchmark before the transactions in terms of turnover growth.

The dramatic recession, which followed the huge investments in new technology in the telecom sector, can be seen in the current telecom industry profitability. The industry benchmark return on assets announced by Reuters was only $3.39 \%$ in March 2004 for Communications services sector and even less for Computer networks sector (Table 8). The outcome of this study yields similar results. In 2002 , the industry median was only $1.88 \%$ perhaps due to the huge amounts of debt taken for investments in new technology. In 2001, the same figure was $3.60 \%$.

It is equally interesting to notice Reuters' debt to equity-ratio for the Communications services industry. Debt to equity-ratio of 0.953 means that the Equity ratio for this industry is little over $50 \%$. Thus, we can suggest also based on this that the telecom corporations that have been performing large-scale real estate sale and leasebacks in Europe have certainly been much more heavily leveraged than the industry in general. Similar assumptions can be made from the current ratio, which is also much higher than in our sample group. However, as already mentioned the time period is very different than in our case, the calculation methods can vary and many of the corporations' markets are different from our sample.

\section{CONCLUSIONS}

The purpose of this research paper was to study the effects of real estate sale and leasebacks on the corporate performance ratios. Subsequently, the study investigated whether the performance ratios of the retail and telecom corporations disposing of operational corporate real estate were significantly worse than the industry benchmark before the transactions.

Some evidence was found that the retail corporations that have been disposing of operational corporate real estate were less profitable as opposed to other corporations in the same business sector before the transactions. It might be that these corporations had much larger real estate holdings than the corporations in the retail sector on average, which had led to a lower, on average, return on total assets. On the other hand, the telecom corporations that have been performing real estate sell-offs had generally worse capital structure and short-term solvency than the corporations in the same business sector before the transactions. In this case the real estate disposals were seen more as a fast way to improve corporations' solvency and capital structure.

All the corporations that sold over $10 \%$ of their total assets as real estate disposals between the years 1998-2001 were able to improve their profitability. Most of them also improved their capital structure and short-term solvency, even though the business cycle at the same time was not very good. In addition, over half of the total 22 corporations under investigation were able to improve their profitability, capital structure or short-term solvency despite the slump in the world economy. The effect on performance ratios was clearest in the retail sector, where nine out of the total twelve studied corporations were able to improve average return on total assets, when at the same time only $30 \%$ of the other corporations were able to do this. Similarly, nine out of the total twelve retail corporations increased their dividend payments after the real estate sell-offs, when at the same time only one corporation from all other business sectors managed to do this.

In future studies, it would be interesting to see more evidence of the underlying reasons for the corporate real estate sale and leasebacks direct from the seller-corporations. This could be done, for instance, as a case study or by means of an interview study. It would 
also be interesting to study how these property outsourcings have succeeded, and whether the corporate and corporate real estate performance has been better after the transactions than before them.

\section{REFERENCES}

Alvayay, J.R., Rutherford, R.C. and Smith, W.S. (1995) The Tax rules and sale and leaseback of corporate real estate, Real Estate Economics, 23(2), p. 207.

Ambrose, B.W. (1990) Corporate real estate's impact on the takeover market, Journal of Real Estate Finance and Economics, 3(4), p. 307-322.

Ball, J.N., Rutherford, R.C. and Shaw, R.J. (1993) The wealth effects of real estate spin-offs, Journal of Real Estate Research, 8(4), p. 597-606.

Benjamin, J.D., De La Torre, C. and Musumeci, J. (1998) Rationales for real estate leasing versus owning, Journal of Real Estate Research, 15(3), p. 223-237.

Brounen, D. and Eichholtz, RM.A. (2003) Corporate Real Estate Ownership and Firm Performance; International Evidence, Journal of Real Estate Finance and Economics, 26(1), under review.

Deng, Y. and Gyourko, J. (2000) Real Estate Ownership by Non-Real Estate Firms: An Estimate of the Impact on Firm Returns, Working Paper Zell/Lurie Real Estate Center at Wharton University of Pennsylvania.

Foster G. (1978) Financial Statement Analysis, Prentice-Hall.

Hite G.L., Owers J.E. and Rogers R.C. (1984) The Separation of real estate operations by spinoff, AREAU Journal, 12(3), p. 318-332.
John TA. (1993) Optimally of Spin-offs and allocation of debt, Journal of Financial and Quantitative Analysis, 28(1), p. 139-160.

Kuruvilla, J. (1994) Corporate real estate holdings and the value of the firm, an empirical investigation.

Laposa S. and Charlton M. (2001) European versus US Corporations; A comparison of property holdings. Journal of Corporate Real Estate, 4(1), p. 34-47.

Nappi-Choulet, I. (2002) Corporate property outsourcing in Europe: Present trends and new approach for real estate economics, IPD European property strategies conference 16th and 17th May 2002 in Wiesbaden.

Pottinger G., Dixon T and Marston A. (2002) Occupational Futures? Divesting real estate and corporate PFI, Journal of Property Management, 20(1), p. 31-48.

Rodriquez M. and Sirmans OF (1996) Shareholder wealth and firm-specific human capital: Evidence from real estate management turnover, Working paper, University of Connecticut.

Slowin M.B., Susbka M.E. and Polonchek J.A. (1990) Corporate sale and lease back and shareholder wealth, Journal of Finance, 45(1), p. 289-299.

Stulz R. and Johnson H. (1985) An analysis of secured debt, Journal of Financial Economics, 14, p. 501-521.

Wainwright S. (2000) Off-balance-sheet property ownership structures, releasing capital from operational portfolios through divestment, Journal of Corporate Real Estate, 2(4), p. 330-342.

Zeckhauser S. and Silverman R.A. (1983) Rediscover your company's real estate, Harvard Business Review, January/February. 
APPENDIX 1: TIME-SERIES USED IN THE STUDY

\begin{tabular}{|c|c|c|c|c|c|c|c|c|c|}
\hline \multicolumn{10}{|c|}{ RETURN ON TOTAL ASSETS (ROA) • } \\
\hline 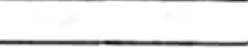 & Deal year(s) & 1996 & 1997 & 1998 & 1999 & 2000 & 2001 & 2002 & 2003 \\
\hline British Telecom & 2001 & & & & $9,8 \%$ & $6,3 \%$ & $6,5 \%$ & $10,6 \%$ & \\
\hline Carrefour & $2001,-03$ & & & & $6,3 \%$ & $7.0 \%$ & $6,5 \%$ & $7,3 \%$ & $8,3 \%$ \\
\hline Ericsson & 2000 & & & $11.3 \%$ & $9,1 \%$ & $13,0 \%$ & $-10,5 \%$ & & \\
\hline France Telecom & 2001 & & & & $8,1 \%$ & $5,3 \%$ & $4,0 \%$ & $5,8 \%$ & \\
\hline Kesko & 1998, $-99,2000$ & $3,3 \%$ & $4,3 \%$ & $9,2 \%$ & $8.2 \%$ & $4.6 \%$ & $3,0 \%$ & & \\
\hline Marks \& Spencer & 2001 & & & & $12,6 \%$ & $5,9 \%$ & $8,6 \%$ & $10,9 \%$ & \\
\hline Metro & 1999 & & $0.5 \%$ & $5,5 \%$ & $8.6 \%$ & $4,6 \%$ & & & \\
\hline MF & 1999 & & $11.2 \%$ & $-1.4 \%$ & $5,0 \%$ & $8,2 \%$ & & & \\
\hline Sainsbury & 2000 & & & $8,8 \%$ & $5,1 \%$ & $5,1 \%$ & $5,8 \%$ & & \\
\hline SAS & 2001 & & & & $4,1 \%$ & $6,5 \%$ & $-1,5 \%$ & $1.1 \%$ & \\
\hline Sireo/DT & 2001 & & & & $14.3 \%$ & $2,8 \%$ & $9.5 \%$ & $2,3 \%$ & \\
\hline Somerfield & $2001,-02$ & & & & $-5,5 \%$ & $-0,4 \%$ & $2,0 \%$ & $1,5 \%$ & $2,6 \%$ \\
\hline SwissCom & 2001 & & & & $13.1 \%$ & $8,5 \%$ & $23,8 \%$ & $8.3 \%$ & \\
\hline Telecom Italia & $2000,-02$ & & & $10,6 \%$ & $14.1 \%$ & $12,2 \%$ & $10,4 \%$ & $12,8 \%$ & $8.3 \%$ \\
\hline Thales & 2001 & & & & $3.7 \%$ & $3,0 \%$ & 2,6 策 & $2,4 \%$ & \\
\hline The Hilton Group & 2001 & & & & $7,5 \%$ & $9,0 \%$ & $7.1 \%$ & $7,0 \%$ & \\
\hline Thomson Multimedia & 2000 & & & $4,4 \%$ & $8,5 \%$ & $8,9 \%$ & $7,4 \%$ & & \\
\hline WH Smith & 1999 & & $6.5 \%$ & $13,7 \%$ & $7,1 \%$ & $15,9 \%$ & & & \\
\hline
\end{tabular}

- the time-series data include two financial statements before and after the deal, ROA:s were calculated as stated in table 1

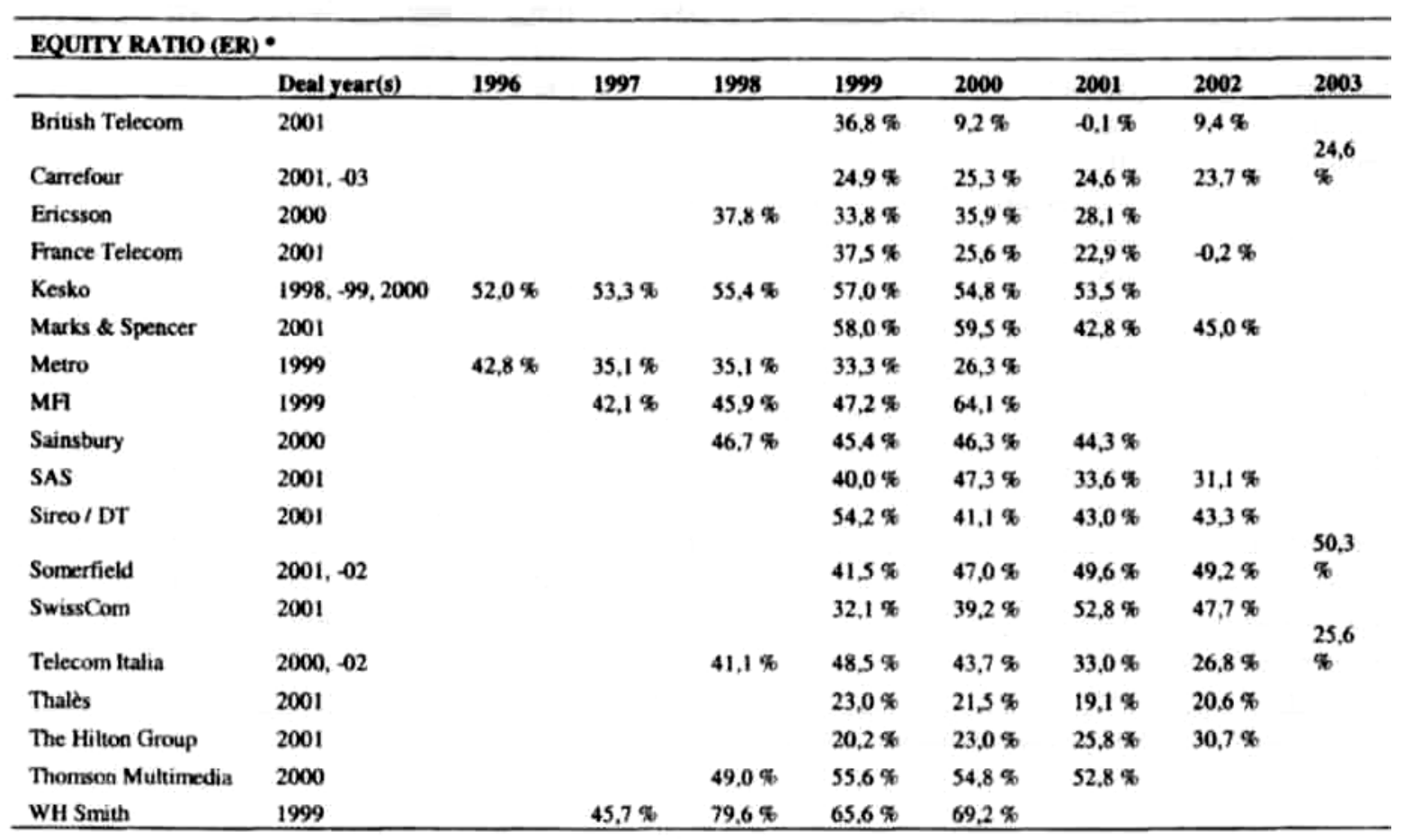

* the time-series data include two financial statements before and after me deal, ER:s were calculated as stated in table 1 


\begin{tabular}{|c|c|c|c|c|c|c|c|c|c|}
\hline \multicolumn{10}{|c|}{ CURRENT RATIO (CR) • } \\
\hline & Deal year(s) & 1996 & 1997 & 1998 & 1999 & 2000 & 2001 & 2002 & 2003 \\
\hline British Telecom & 2001 & & & & 0.52 & 0,46 & 0,11 & 1.13 & \\
\hline Carrefour & 2001. -03 & & & & 0.39 & 1.40 & 1,85 & 0,83 & 0,82 \\
\hline Ericsson & 2000 & & & 0,83 & 1,89 & 2.13 & 2,02 & & \\
\hline France Telecom & 2001 & & & & 0.78 & 0.32 & 0.66 & 0.31 & \\
\hline Kesko & $1998,-99,2000$ & 0,91 & 0.95 & 0,90 & 0,89 & 0.73 & 0.72 & & \\
\hline Marks \& Spencer & 2001 & & & & 0.97 & 0,99 & 1.20 & 1,04 & \\
\hline Metro & 1999 & & 0,88 & 0,93 & 1,08 & 0,93 & & & \\
\hline MF & 1999 & & 0,62 & 0,63 & 0,59 & 0.73 & & & \\
\hline Sainsbury & 2000 & & & 0.79 & 0,76 & 0,86 & 0,79 & & \\
\hline SAS & 2001 & & & & 0.95 & 0,95 & 0.91 & 0.82 & \\
\hline Sireo / DT & 2001 & & & & 0,89 & 0.35 & 0.52 & 0.27 & \\
\hline Somerfield & $2001 .-02$ & & & & 1,16 & 0,88 & 0.79 & 0.70 & 0,80 \\
\hline SwissCom & 2001 & & & & 0,63 & 0,89 & 1,96 & 1,31 & \\
\hline Telecom Italia & $2000,-02$ & & & 0,72 & 0,73 & 0,60 & 0,76 & 0,89 & 0,75 \\
\hline Thales & 2001 & & & & 1,00 & 1,16 & 2.66 & 2,66 & \\
\hline The Hilton Group & 2001 & & & & 1,21 & 1,30 & 1.10 & 1,10 & \\
\hline Thomson Multimedia & 2000 & & & 0,91 & 0,86 & 2.06 & 1.62 & & \\
\hline WH Smith & 1999 & & 1,09 & 0,83 & 0,94 & 0,95 & & & \\
\hline
\end{tabular}

- the time-series data include two financial statements before and after the deal, CR's were calculated as stated in table 1

\begin{tabular}{|c|c|c|c|c|c|c|c|c|c|}
\hline \multicolumn{10}{|c|}{ DIVIDEND PER SHARE (DPS) • } \\
\hline & Deal year(s) & 1996 & 1997 & 1998 & 1999 & 2000 & 2001 & 2002 & 2003 \\
\hline British Telecom & 2001 & & & & 0.14 & 0,05 & 0,01 & 0,05 & \\
\hline Carrefour & $2001 .-02$ & & & 0.41 & 0,45 & 0,50 & 0,56 & 0.64 & 0.74 \\
\hline Ericsson & 2000 & & & 0,04 & 0.04 & 0,04 & 0,00 & & \\
\hline France Telecom & 2001 & & & & 1.00 & 1,00 & 1,00 & 0,00 & \\
\hline Kesko & $1998,-99,2000$ & 0,34 & 0,50 & 0,67 & 0.50 & 1,00 & 0,60 & & \\
\hline Marks \& Spencer & 2001 & & & & 0,06 & 0,06 & 0,07 & 0,05 & \\
\hline Metro & 1999 & & 2,03 & 1,02 & 1.02 & 1,02 & & & \\
\hline MFI & 1999 & & 0.07 & 0,01 & 0,02 & 0.03 & & & \\
\hline Sainsbury & 2000 & & & 0.20 & 0.20 & 0,20 & 0,21 & & \\
\hline SAS & 2001 & & & & 0.44 & 0.50 & 0,00 & 0,00 & \\
\hline Sireo / DT & 2001 & & & & 0.62 & 0.62 & 0.37 & 0,00 & \\
\hline Somerfield & $2001,-02$ & & & & 0,02 & 0,00 & 0,14 & 0.24 & 0.31 \\
\hline SwissCom & 2001 & & & & 9.68 & 7.10 & 7.10 & 3.23 & \\
\hline Telecom Italia & 2000, -02 & & & 0,15 & 0,32 & 0,32 & 0,32 & 0,32 & 0.12 \\
\hline Thales & 2001 & & & & 0.60 & 0.60 & 0.70 & 0.00 & \\
\hline The Hilton Group & 2001 & & & & 0.07 & 0,07 & 0,07 & 0,07 & \\
\hline Thomson Multimedia & 2000 & & & 0.00 & 0,00 & 0.00 & 0,00 & & \\
\hline WH Sinith & 1999 & & 0,22 & 0,24 & 0,26 & 0,27 & & & \\
\hline
\end{tabular}

* the time-series data include two financial statements before and after the deal, dividends are in euros 


\begin{tabular}{|c|c|c|c|c|c|c|c|c|c|}
\hline \multicolumn{10}{|c|}{ TURNOVER GROWTH (TG) • } \\
\hline & Deal year(s) & 1996 & 1997 & 1998 & 1999 & 2000 & 2001 & 2002 & 2003 \\
\hline British Telecom & 2001 & & & & $20.2 \%$ & $35,4 \%$ & $-16,9 \%$ & $-18.1 \%$ & \\
\hline Carrefour & $2001 .-02$ & & & & $5,1 \%$ & $24.7 \%$ & $7,2 \%$ & $-1,1 \%$ & $2,6 \%$ \\
\hline Ericsson & 2000 & & & $10,1 \%$ & $16,8 \%$ & $27.0 \%$ & $-15,3 \%$ & & \\
\hline France Telecom & 2001 & & & & $23.7 \%$ & $27.8 \%$ & $8,4 \%$ & $4.9 \%$ & \\
\hline Kesko & $1998,-99,2000$ & $0,6 \%$ & $18,6 \%$ & $2.1 \%$ & 2,0 第 & $3.2 \%$ & $-1,5 \%$ & & \\
\hline Marks \& Spencer & 2001 & & & & $-0.3 \%$ & $-1,5 \%$ & $0.7 \%$ & $-0.7 \%$ & \\
\hline Metro & 1999 & & Puute! & $61,3 \%$ & $-6.5 \%$ & $7.1 \%$ & & & \\
\hline MFI & 1999 & & $5,4 \%$ & $-8,9 \%$ & $-2,0 \%$ & $13,4 \%$ & & & \\
\hline Sainsbury & 2000 & & & $5.7 \%$ & $6.3 \%$ & $5.9 \%$ & $-1.3 \%$ & & \\
\hline SAS & 2001 & & & & $22,9 \%$ & $87,6 \%$ & $-9,2 \%$ & $-3,7 \%$ & \\
\hline Sireo / DT & 2001 & & & & $-11.0 \%$ & $3,6 \%$ & $-2,3 \%$ & $-6,3 \%$ & \\
\hline Somerfield & 2001. -02 & & & & $-7,3 \%$ & $-15,6 \%$ & $0,6 \%$ & $0.6 \%$ & $-3,2 \%$ \\
\hline SwissCom & 2001 & & & & $6.0 \%$ & $27,5 \%$ & $1.4 \%$ & $2,8 \%$ & \\
\hline Telecom Italia & $2000,-02$ & & & Puute! & $8,2 \%$ & $6.7 \%$ & $6,6 \%$ & $-1,4 \%$ & $1.5 \%$ \\
\hline Thalès & 2001 & & & & $11,6 \%$ & $24,5 \%$ & $19,7 \%$ & $8,2 \%$ & \\
\hline The Hilton Group & 2001 & & & & $-8.1 \%$ & $-8.1 \%$ & $5.3 \%$ & $31,6 \%$ & \\
\hline Thornson Multimedia & 2000 & & & $-2,7 \%$ & $17.6 \%$ & $35.9 \%$ & $15.5 \%$ & & \\
\hline WH Smith & 1999 & & $-0,6 \%$ & $0.2 \%$ & $-15,2 \%$ & $8.1 \%$ & & & \\
\hline
\end{tabular}

* the time-series data include two financial statements before and after the deal 